\title{
Does Health Affect Portfolio Choice?
}

\author{
David A. Love* \\ Paul A. Smith ${ }^{\dagger}$
}

May 22, 2008

\begin{abstract}
Previous studies find a strong and positive empirical connection between health status and the share of risky assets held in household portfolios. But is this relationship truly causal, in the sense that households respond to changes in health by altering their portfolio allocation, or does it simply reflect unobserved differences across households? We find that the link between health and risky assets depends crucially on the econometric treatment of unobserved heterogeneity. Once we account adequately for unobserved household differences, we find no statistically significant effect of health status on either portfolio allocations or ownership among older households (those with respondents 70 and older) in the Health and Retirement Study. Younger households, in contrast, do seem to adjust their portfolios on both the extensive and intensive margins in response to health shocks.
\end{abstract}

JEL classification: G11; I10

Keywords: Household portfolios; Health; Risk

\footnotetext{
*Dept. of Economics, Williams College, Williamstown, MA 01267, david.love@williams.edu.

${ }^{\dagger}$ Federal Reserve Board, 20th and C St., NW, Washington, DC 20551, paul.a.smith@frb.gov. We are grateful to Jon Bakija, Michael Palumbo, and Maria Perozek for their helpful insights and Lucy McNair for outstanding research assistance. We also thank seminar participants at Williams College and the Federal Reserve Board for helpful comments. The views expressed herein are those of the authors and do not necessarily reflect those of the Board of Governors or the staff of the Federal Reserve System.
} 


\section{Introduction}

Does health status affect portfolio choice? The life-cycle theory of saving suggests several reasons to expect a relationship. Most directly, health shocks could affect the marginal utility of consumption and therefore alter households' valuation of risk. ${ }^{1}$ Additionally, if uncertain medical expenses increase background risk (in a manner similar to income volatility), then declining health may make risky investments less desirable. ${ }^{2}$ Finally, a decline in health may lead to lower future income due to reduced labor supply or lower life expectancy. Since future income can substitute for safe assets in a household's portfolio (Bodie, Merton, and Samuelson, 1992), declining health could increase the demand for safe financial assets.

Several empirical studies find that poor health is indeed associated with a safer household portfolio allocation. Rosen and $\mathrm{Wu}$ (2004) find that poor health is associated with a reduction in the probability of owning any stocks or mutual funds of about 1.7 percentage points and a reduction in the share of risky assets of around 2 percentage points. Edwards (forthcoming) uses a similar estimation strategy and also finds a negative effect of poor health on the stock share of assets. Christelis, Jappelli, and Padula (2006) find small negative correlations between poor health and stock-holding in a cross-sectional data-set covering ten major European countries. Coile and Milligan (2006) perform "event studies" of health changes and find a small negative effect of a chronic health shock on the probability of holding IRAs or stocks, though no effect on the marginal share. Berkowitz and Qiu (2006), however, find that the relationship between health and portfolio allocation mostly disappears after controlling adequately for differences in financial wealth between sick and healthy households.

Indeed, one major concern with many of the empirical studies is that a correlation between health and portfolio choice could reflect unobserved heterogeneity across households rather than a causal link. For example, if unobserved characteristics such as risk attitudes and impatience are correlated with both health status and portfolio choice, a regression might uncover a statistically significant correlation even in the absence of a causal relationship. Some of the previous studies (e.g., Rosen and Wu (2004) and Edwards (forthcoming))

\footnotetext{
${ }^{1}$ As pointed out by Edwards (2006, 2007, forthcoming), health shocks could either increase or decrease the marginal utility of consumption. For example, diminished health could reduce the enjoyment of some leisure activities, such as playing golf, taking a trip, or eating out. On the other hand, worsening health could increase the marginal value of labor-saving consumption, such as taxi rides or cleaning services.

${ }^{2}$ Pang and Warshawsky (2008) find in a numerical model of health expenses and portfolio choice that medical expense risk generates a shift away from risky assets. French and Jones (2004) find in a dynamic programming model with uncertain medical expenses that both medical expense shocks and the uncertainty surrounding future expenses can have a substantial effect on consumption and saving decisions. Finally, as demonstrated in Hubbard, Skinner, and Zeldes (1995), the social insurance floor provided by Medicaid could distort the incentives of lower-wealth households. We do not emphasize this channel, however, since few stock holders in the data qualify as having low wealth.
} 
attempt to control for unobserved heterogeneity by utilizing panel data in a random-effects regression framework. However, this approach requires a strong assumption of zero correlation between the unobserved effect and right-hand-side variables; in the presence of such correlation, the coefficient estimates are inconsistent. ${ }^{3}$

In this paper, we control more carefully for unobserved heterogeneity by utilizing the 1998 through 2006 waves of the Health and Retirement Study in correlated random effects and fixed effects specifications that do not impose the strong assumptions required by random effects models. We find that younger households (ages 51 to 70) do appear to adjust their portfolio allocations a bit in response to changes in self-reported health status, but not to increases in out-of-pocket medical costs. Older households (over age 70), in contrast, show little responsiveness to our health measures. This pattern is suggestive of different channels connecting health and portfolio decisions at different ages. We conclude that there is little evidence that older households adjust their stock portfolios in response to health shocks.

\section{Data}

Like several previous studies (Berkowitz and Qiu, 2006; Coile and Milligan, 2006; Rosen and $\mathrm{Wu}, 2004)$, we use the Health and Retirement Study (HRS), which is particularly wellsuited because it provides longitudinal data on both health status and household portfolios. However, unlike previous studies, we begin with the 1998 wave because it is the first to represent all cohorts aged 51 and over. ${ }^{4}$ Our sample is therefore older, on average, and more representative of aged households than those used in the previous studies.

Table 1 provides a few demographic statistics for our sample. For the entire sample of 13,703 households, the average age is about 66 years, about 7 years older than the average reported for single households in Rosen and $\mathrm{Wu}$ (2004). While about half of the entire sample is married, single females make up about 47 percent of the older subsample. Most households report having children (only 10 percent do not), and there are, on average, about three children per household.

\footnotetext{
${ }^{3}$ Rosen and $\mathrm{Wu}$ (2004) also address the unobserved heterogeneity problem by including survey responses related to preferences about risk, planning horizons, and expectations. However, it is difficult to imagine that all unobserved heterogeneity can be removed.

${ }^{4}$ The original 1992 cohort of the HRS included households aged 51-61 in 1992. The cohorts added in the 1998 wave are the War Baby cohort (aged 51-56 in 1998), the Children of the Depression cohort (68-74), and the Aging and Health Dynamics cohort (75 and older). Since the HRS cohort was aged 57-67 in 1998, the 1998 waves thus covers the full population of households aged 51 and older. The obvious downside of beginning in 1998 is that the panel is shorter (five waves rather than eight), but in this case we decided it was more valuable to represent the full age distribution than to have a longer panel.
} 


\subsection{Wealth Measures}

Our measures of stock-holding include directly held stocks and stocks held in mutual funds and trusts, but exclude stocks held in retirement accounts. While many households own stocks in retirement accounts, we focus on the narrower definition (excluding retirement accounts) because it has less measurement error and thus offers a cleaner test of the relationship between health and portfolio choice. ${ }^{5}$

Table 2 shows the evolution of household wealth and portfolio shares from 1998 to 2006. In this table, we define our age groups according to the older household member's age in 1998 and follow the cohorts forward throughout the time period. The table shows several important differences between younger and older households. For example, older households have more financial wealth but much less retirement wealth, reflecting both a cohort effect (e.g., younger households are more likely to have participated in 401(k) plans) and a drawdown effect of older households tapping retirement wealth. Older households also have more nonfinancial wealth than younger households and are less likely to own stock, particularly in later years. Those that do own stock, however, hold more than their younger counterparts, resulting in similar stock shares of financial wealth.

For both groups real net financial wealth rises considerably toward the end of the sample period, by about $\$ 62,000$ (61 percent) for younger households and by about $\$ 34,000$ (25 percent) for older households. Non-financial wealth, consisting mostly of housing, rises even more, reflecting the dramatic gains in house prices over this period. At the same time, stock ownership rates drop throughout the sample period, with a net decline of 10 percent for younger households and about 13 percent for older households. In contrast, the stock shares of financial wealth are relatively constant across time for older households but fall noticeably in 2004 and 2006 for the younger age group.

\section{$2.2 \quad$ Health Measures}

We focus on two measures to capture respondents' current health: self-reported health status and out-of-pocket medical expenses. Respondents can describe their current health status as "excellent," "very good," "good," "fair," or "poor." The self-reported health

\footnotetext{
${ }^{5}$ The HRS asks respondents directly about the value of stock shares held by themselves, in mutual funds, and in trusts, but it does not ask directly about the value of stocks held in retirement accounts. Rather, for both IRAs and DC plans, the survey asks, "Is the money in this account invested mostly in stocks, mostly in interest-earning assets, is it about evenly split between these, or what?" To test whether our results are sensitive to our definition of the stock share, we re-estimated all of our equations with a more comprehensive measure of stock holding that uses simple but fairly crude rules to map the survey responses into retirementaccount stock shares. We find that the broader definition of the stock share does not materially affect our findings about health and portfolio choice.
} 
variable is ranked 1 to 5 , with 1 for "excellent" and 5 for "poor." 6

Out of pocket (OOP) medical expenses include uninsured costs over the previous two years related to the following: doctor visits, outpatient surgery, hospital and nursing home stays, prescription drugs, home health care, and special medical facilities or services. As is well-known, the cross-sectional distribution of medical expenses is characterized by a very long upper tail (see e.g., French and Jones, 2004). ${ }^{7}$ In our regression analysis, we therefore use the natural logarithm of OOP expenses. Medical expenses are different from the other two health measures in that they are more endogenous - they are likely to reflect a household's propensity to spend on discretionary medical care as well as underlying health status. We include them because they are an important theoretical channel of causal health effects, but their potential endogeneity highlights the importance of accounting adequately for unobserved preference and attitudinal differences across households.

The HRS also provides an "objective" measure of health - indicators of doctor diagnoses of high blood pressure, diabetes, cancer, lung disease, heart problems, stroke, psychiatric problems, and arthritis. We focus on the "subjective" self-report because it is more likely to be related to behavioral changes such as portfolio reallocations. For example, two households could receive the same diagnosis but report different effects on their self-report of health - either because the conditions are of varying severity, or because of differences in attitude toward the health shock (e.g., "stoic" vs. "vulnerable").

Indeed, some evidence for a disconnection between self-reported health and the number of health conditions can be seen in Table 3, which shows the evolution of the health measures over the sample period. The two age groups show remarkably little change in average selfreported health over time. Younger households report an average health status of about 3 (corresponding to "good") and older households consistently average around 3.3 (edging a bit closer to "fair"). In contrast to the stable behavior of self-reported health, the number of doctor diagnosed medical conditions increases markedly over the time period for both age groups. One possibility is that the rates of diagnosis increased over this time period for reasons unrelated to actual health condition changes (e.g., earlier diagnosis of less-severe cases). Another explanation, related to the psychological literature on happiness (see, e.g., Gilbert 2006), is that individuals adapt to income and health shocks and reset to some baseline level of well-being. ${ }^{8}$

\footnotetext{
${ }^{6}$ Rosen and $\mathrm{Wu}(2004)$ estimate the impact of a health status variable defined as "fair" to "poor," omitting the other categories. As a robustness check, we also estimate our models with their health status variable, and we find no statistically significant changes in our estimates.

${ }^{7}$ For example, in our HRS sample, while median OOP expenses are about $\$ 1,300$ over a two-year period, the 90 th percentile is about $\$ 7,300$ and the 99 th percentile is about $\$ 38,000$ for singles.

${ }^{8}$ When we repeat our analysis using the number of diagnosed conditions in place of self-reported health, we obtain similar results but with smaller and less precisely estimated coefficients. We also repeated our analysis using an indicator for the "worst" conditions, which we somewhat arbitrarily defined as cancer, lung disease, and heart problems, and found substantially similar results.
} 
Table 3 also shows that over the 8-year time period medical costs increased by about 125 percent for older households and by about 80 percent for younger households. The increase probably reflects a combination of age-related declining health and a general increase in health expenses above CPI inflation.

\subsection{Controls}

In our regression specifications, we relate stock holding and asset allocation to our health measures and other covariates. Controls include wealth, income, age, sex, education, race, and other household demographics. In models such as these there is often some concern about endogeneity, since factors affecting stock holding and health can also affect wealth and income. To help address this issue, we first control separately for financial wealth, nonfinancial wealth, and non-capital income. ${ }^{9}$ We treat these separately because the relationship between health and wealth could vary across types of wealth - indeed, Berkowitz and Qiu (2006) find that health changes affect financial wealth more than nonfinancial wealth, and that the effect of health on portfolio choice seems to disappear when differences in financial wealth are controlled for. Second, because retired households may respond differently to health shocks than working households, we split the sample by age and also include an indicator variable for whether the household receives Social Security retirement benefits. Finally, and most importantly, we explicitly control for unobserved heterogeneity using two different methodologies, as described in the section below.

To control for the role of expected bequests in household portfolio decisions, we also include the subjective probability that the household will leave an inheritance of at least $\$ 100,000$. About 54 percent of singles report a probability less than 20 percent of leaving a bequest, 15 percent report a probability between 20 and 80 percent, and 31 percent report a probability higher than 80 percent. Couples are more likely to report a good chance of a bequest, with about a third reporting a low probability and just under half reporting a high probability.

Since the effect of health on household decisions may depend critically on health insurance coverage, particularly for younger households who do not yet qualify for Medicare, we include a control for whether each member of the household has some form of health insurance (government, employer, or other). While about 98 percent of older households are insured, the figure drops to about 85 percent among younger households.

A concern pertaining to all studies of health and wealth is the possibility that causality might run in either direction. If wealth gains improve health, either through improving access to health care or through some other channel, a causal interpretation of the estimates

\footnotetext{
${ }^{9}$ Following Hochguertel (2003), we transform the wealth and income variables using the log odd function: $f(x)=\ln (x+1)$ if $x>0$, and $f(x)=-\ln (-x+1)$ if $x \leq 0$.
} 
on our health variables would be problematic. A recent study (Michaud and van Soest, 2008), however, tests for reverse causality using dynamic panel data models that control for unobserved heterogeneity and finds no evidence that changes in wealth drive changes in health. If wealth does not influence health, we conclude that there is little reason to expect that portfolio shares or ownership would have an independent effect on health.

\subsection{Descriptive Analysis}

The left-hand columns of Table 4 show average portfolio allocations by our various health measures. There is clearly a positive correlation between health and stock allocation. Younger households in the top self-rated health group have about 13 percent more of their financial portfolios allocated to stock, on average, than those in the bottom health group, while for older households, the difference is about 9 percentage points. A similar result holds when looking at diagnosed conditions. When we move to out-of-pocket expenses, however, we see a different pattern: households in the middle third allocate about 6 percentage points more to stock than the lower group, and there is little difference between the middle and upper OOP groups. The difference between the OOP pattern and the other health measures suggests that OOP may measure something quite different from health status: perhaps the ability or willingness to pay for medical care, or a preference for a greater amount or higher quality care. Alternatively, it could represent a mechanical effect in which high expenses are financed out of liquid (non-stock) assets, driving up the portfolio shares.

One question that arises from these results is whether the difference in portfolio allocation by health is coming from the extensive or intensive margins (or both) - that is, whether sicker households are less likely to own any stocks, and/or less likely to hold smaller stock shares conditional on owning any. The right-hand columns of the table show that there is a large difference on the extensive margin: households in the lowest self-rated health group are 20 to 25 percentage points less likely to hold any stocks than those in the highest group. On the other hand, there is little variation on the intensive margin: conditional on owning any stocks, the average share allocated to equities is between 45 percent and 50 percent for all health groups. ${ }^{10}$ This result suggests that the association between health and portfolio allocation could have more to do with factors that explain why some households don't hold any stock, rather than factors that influence the amount of stock held on the margin.

This observation leads us to the central question of our paper: is the difference in portfolio allocation by health status causal, or is it explained by other correlated (and potentially unobserved) factors? To investigate the extent of causality, we turn to our correlated random effects and fixed effects specifications.

\footnotetext{
${ }^{10}$ We obtain similar results when we compare across marital status groups (not shown for brevity).
} 


\section{Estimation Strategy}

\subsection{Econometric Models}

Our empirical approach exploits the panel nature of the data to account for unobserved household effects that might influence both portfolio choice as well as some of our explanatory variables. Following earlier studies, we first estimate binary response models (probits and logits) to identify the effect of health on the extensive margin of stock ownership. We then estimate censored regression models to uncover the link between health and the marginal stock allocation.

We begin with a standard random effects specification very similar to those used in earlier studies, and then apply a correlated random effects approach and a fixed effects estimator to test the robustness of the relationship between health and portfolio choice.

\subsubsection{Random Effects Probits and Tobits}

First we estimate a standard random effects probit model for stock ownership and random effects Tobit model for marginal allocation. Underlying all of the specifications is a latent variable model of the form:

$$
y_{i t}^{*}=\mathbf{x}_{i t} \beta+c_{i}+u_{i t},
$$

where $\mathbf{x}_{i t}$ is a vector of exogenous explanatory variables, $c_{i}$ is an unobserved, time-invariant, individual-specific effect, and $u_{i t}$ is an idiosyncratic error. In the participation equations, the dependent variable $y_{i t}$ is an indicator for holding positive amounts of risky assets, such that $y_{i t}=1$ if $y_{i t}^{*}>0$. In the stock-share regressions, $y_{i t}^{*}$ represents the desired portfolio share, but the observed risky asset shares lie between 0 and 1 , so that $y_{i t}=\max \left\{0, \min \left\{y_{i t}^{*}, 1\right\}\right\}$.

It can be seen from the specification above that failing to account for unobserved effects will generally lead to biased coefficient estimates unless the omitted variables are perfectly uncorrelated with any of the independent variables in the regression. The bias comes from a violation of the orthogonality assumption applied to the composite error in the latent variable model above. In a pooled regression, $E\left(\mathbf{x}^{\prime}{ }_{i t} \mid\left(c_{i}+u_{i t}\right)\right)$ will generally be nonzero if the unobserved factor $c_{i}$ is correlated with the observables $\mathbf{x}_{i t}^{\prime}$. The standard random

effects models obtain coefficient estimates by integrating the unobserved factor $c_{i}$ out of the likelihood function. However, consistency requires that $E\left(c_{i} \mid \mathbf{x}_{i 1}, \ldots, \mathbf{x}_{i T}\right)=E\left(c_{i}\right)=0$, which is violated whenever there is correlation between $c_{i}$ and any of the $\mathbf{x}_{i t}$ 's. That is, the random effects estimator is only consistent in the special case that the unobserved effect is uncorrelated with the observables - unlikely in this context, because some of the key parameters in the life cycle model, such as risk preference, impatience, and longevity are unobserved and likely to be correlated with education, wealth, and other observables. To 
some extent, we can control for these factors by including proxy variables, such as subjective survival probabilities, but these are at best imperfectly measured, and the omitted variables problem remains. A more promising approach would be to attempt to account for the correlation between the unobserved random effect and the observables, or better yet, to difference out the individual effects via a fixed-effects strategy.

\subsubsection{Correlated Random Effects Probits and Tobits}

Our next step is to account for the potential correlation between unobserved and observed variables using a correlated random effects regression in the spirit of Chamberlain (1984). ${ }^{11}$ The correlated random effects approach assumes that the individual effect $c_{i}$ can be written a linear function of the explanatory variables:

$$
c_{i}=\Psi+\overline{\mathbf{x}}_{i} \lambda+a_{i}, a_{i} \mid \mathbf{x}_{\mathbf{i}} \sim N\left(0, \sigma_{a}^{2}\right),
$$

where the vector $\overline{\mathbf{x}}_{i}$ contains the means of the time-varying regressors, $\Psi$ is a constant, and $a_{i}$ is the independent portion of the individual effect. ${ }^{12}$

In our context, if health is correlated with stock ownership in this specification, then we have a bit more evidence that the correlation is indicative of a causal effect rather than spurious correlation. However, this approach requires three assumptions: first, that the relationship between unobservables and observables is linear; second, that there are not other sources of unobserved heterogeneity; and, third, that the errors are normally distributed. If these conditions do not hold, our omitted variable problem remains. Thus, our final specification attempts to difference out individual effects altogether using a fixed effect approach.

\subsubsection{Conditional Fixed Effect Logit and Censoring Models}

In general, fixed effect differencing cannot be applied to nonlinear models such as ours, because the nonlinearity implies that differencing would not remove the individual effect. However, Chamberlain (1980) showed that, in the binary choice case, a logit specification in which the likelihood function is conditioned on the number of observations with $y_{i t}=1$ can be constructed in a way that effectively removes unobserved heterogeneity from the choice probabilities. This estimator, called the conditional fixed effect logit estimator, can be used to obtain fixed effect estimates from longitudinal binary choice data, such as stock ownership.

\footnotetext{
${ }^{11}$ For recent applications of this model to portfolio choice, see Bakija (2004) and van Soest and Kapetyn (2006).

${ }^{12}$ An alternative specification would allow $c_{i}$ to depend on the time-varying $x_{i t}$ 's, rather than just their means. The motivation for our specification is that it economizes on degrees of freedom.
} 
In the continuous case, until recently, there was no estimator that could handle a fixed effect specification in the presence of two-sided censoring. However, a new semi-parametric estimator developed by Honoré and Leth-Petersen (2006), which generalizes the one-sided least absolute deviation estimator in Honoré (1992) to handle the case of two-sided censoring, allows us to apply a fixed effects estimator to the marginal allocation problem. ${ }^{13}$

The main strength of the resulting estimator is that it produces consistent estimates of a fixed effect Tobit-type model, and it does so with minimal restrictions on the distribution of the error term (e.g., it need not be normal). A disadvantage of this technique, however, is that it cannot be used to compute the marginal effects in the censored regressions. The marginal effects typically depend on both the estimated parameters as well as the unobserved fixed effects, but the Honoré' estimator strips these away and estimates the coefficients using only time variation in the regressors. Nevertheless, this estimator provides a useful way to test the robustness of the relationship between health and portfolio allocation. ${ }^{14}$

\subsection{Specifications}

Because the effects of health on participation and allocation could very well be different, our analysis proceeds in two steps. In the first, we examine stock ownership independently of allocation, modeling the ownership decision as a binary outcome (while still accounting for unobserved heterogeneity) - first with a standard random effect probit, then a correlated random effect probit, and then Honoré's conditional fixed effect logit model. In the second step, we consider the joint determination of allocation and participation, beginning with a standard random effects Tobit model, then moving to correlated random effects Tobit specifications, and finally Honoré's fixed effects censored regression model. ${ }^{15}$

Because households that are approaching retirement may respond to health shocks very differently than households already in retirement, we run separate regressions for respondents younger than 70 and for those 70 and older. The logic behind the age division is that

\footnotetext{
${ }^{13}$ For recent applications of this estimator to models of portfolio choice, see Alan and Leth-Petersen (2006) and Hochguertel (2003). Hochguertel uses a one-sided FE Tobit to study the effects of precautionary behavior on portfolio choice, and Alan and Leth-Peterson use the two-side model to estimate the importance of marginal tax rates. As far as we know, we are the first to apply the method to analyze the effects of health on portfolio decisions.

${ }^{14}$ We implement Honoré's two-sided LAD estimator using Gauss code available at the author's website: http://www.princeton.edu/ honore/programs/2side.

${ }^{15}$ Ideally, we would like to account for unobservable heterogeneity at the same time as selection into stock holding. The estimator proposed by Kyriazidou (1997), essentially a panel-version of Heckman's (1979) twostep method, suits this purpose nicely. This estimator, however, is identified by observations which move across the extensive margin over time (e.g., go from zero to positive stock holding or vice versa), which is a small and select group in our case. In addition, when we implemented the estimator, we found that it was quite sensitive to assumptions about the bandwidth constant on the kernel function, so that different values would generate very different estimates.
} 
younger households can respond to health shocks by adjusting labor supply, an option not generally available to older households. ${ }^{16}$

\section{Estimation Results}

\subsection{Stock Ownership}

Table 5 shows the results from our three specifications of stock ownership. ${ }^{17}$ The left-hand panel reports the baseline random effects estimates for younger and older households in our sample. ${ }^{18}$ Financial wealth, non-financial wealth, non-capital income, and education are all strongly and positively associated with stock ownership, consistent with previous studies and likely reflecting factors such as financial and/or informational barriers to entry in asset markets. In addition, households expecting to leave a bequest are much more likely to own stock. In terms of household characteristics, single males and older single females are more likely to own stock than married couples (the omitted category), while younger single females are less likely. The coefficients on whether households have children are insignificant.

In this specification, self-reported health is strongly and significantly negatively related to stock ownership for the younger households in the sample. ${ }^{19}$ We estimate a marginal effect of self-reported health (ranked 1-5) of around negative 2.1 percent, which is in the neighborhood of the estimates in Rosen and $\mathrm{Wu} .{ }^{20}$ The marginal effect of self-reported health status is smaller for older households - around negative 0.7 percent - but still negative and significant. Higher log out-of-pocket medical expenses, on the other hand, are associated with higher probabilities of stock ownership - consistent with our descriptive evidence that suggested OOP expenses might have discretionary or "luxury good" aspects. The coefficient on medical costs is roughly twice as large for older households as it is for younger households.

These findings are consistent with Rosen and Wu's (2004) explanation for their empirical findings. Building on the logic in Bodie, Merton, and Samuelson (1992), they argue that

\footnotetext{
${ }^{16}$ An alternative way of dividing the sample is to follow Rosen and Wu (2004) and consider single and married households separately. We experimented with splitting the sample by marital status, but it did not have a significant effect on our general findings about health and portfolio choice. The estimates for couples were generally similar to those for singles, but with smaller coefficients and marginal effects.

${ }^{17}$ In all of the regressions, we restrict our sample to households with more than $\$ 0$ and less than $\$ 6$ million in financial assets.

${ }^{18}$ Table 7 shows the results for the full sample, unconditional on age.

${ }^{19}$ The ratio of the marginal effects to the coefficient estimates is relatively constant across the covariates. To conserve space, we report the average ratios at the bottom of Tables 5-7. They range between 20 and 30 percent for the probit and tobit specifications.

${ }^{20}$ The self-reported health variable in Rosen and $\mathrm{Wu}$ is an indicator for being in fair or poor health. When we estimate our equations using their definition, we obtain nearly identical results as in the specification above. The marginal effect associated with fair to poor health - the Rosen and Wu measure - is negative 2.3 percent. The standard error, however, more than doubles when we move to the indicator health variable.
} 
sick households are less able to absorb low asset returns by adjusting labor supply and therefore tend to shift toward safer portfolio allocations. Under this interpretation, younger households would be more responsive to changes in health status because of the labor supply channel, while older households would worry more about large out-of-pocket medical costs. The question remains, however, whether these findings represent a true causal relationship, or rather bias due to correlation between the random effect and observables.

The middle panel of Table 5 reports the results for the correlated random effects specification, which allows for such correlation. For brevity, we report only the slope coefficients on the regressors of interest, and not the estimated correlations between the unobservables and the independent variables. It is worth noting, however, that many of the latter estimates share the signs and significance levels of the estimates in the random-effects regression, suggesting that the random effects and observables are indeed correlated - a significant violation of a key assumption in the standard random effects specification that results in inconsistent estimates.

In the correlated random effects specification, the marginal effect of health is reduced by almost half among younger households, and we find essentially no correlation among older households. For both age groups, the coefficient estimates on out-of-pocket medical costs become statistically insignificant, with point estimates close to zero. These results suggest that much of the correlation between health and portfolio choice is due to unobserved heterogeneity across households, rather than a causal link.

The right-hand panel of Table 5 shows that the fixed-effects results are similar. ${ }^{21}$ As with all fixed effects estimators, however, this specification has the disadvantage that it only includes explanatory variables that vary within a household over time. Thus we are unable to estimate the slope coefficients of potentially interesting variables such as education, race, and gender. Another drawback associated with the fixed effects estimator is its tendency to exacerbate the effects of measurement error, particularly if there is comparatively limited "within" variation (Bound, Brown, and Mathiowetz, 2001). In our case, the effect of health on ownership is identified by changes in health and stock ownership over our 8-year sample period. If a large fraction of the changes in ownership status simply reflects measurement error, the coefficient estimates may be noisily measured indeed. Because the imprecision of our estimates may be due to measurement error, we interpret our results as evidence against evidence: we do not find any effect of health on risky asset ownership within households. ${ }^{22}$

It may not be surprising to find a weak connection between changes in stock ownership

\footnotetext{
${ }^{21} \mathrm{~A}$ drawback of the conditional fixed effect logit is that one cannot estimate marginal effects at the individual level.

${ }^{22}$ As a robustness check to see whether our results are due to the nonlinear nature of our limited dependent variable, we also estimated a set of fixed effects linear probability models. In these specifications, the health coefficients were also statistically insignificant and close to zero.
} 
and changes in health - should we really expect households who suffer a negative health shock to exit the stock market, or an older individual in improved health to decide to purchase stocks for the first time? On the intensive margin, however, we might expect a more easily measurable relationship. Changes in health status and out-of-pocket medical costs represent substantial background risks that should, according to theory, diminish the demand for risky assets.

\subsection{Stock Allocation}

Table 6 shows the results from our three specifications of stock allocation. The left-hand panel reports the results for our baseline random effects Tobit regression of stock share on health. ${ }^{23}$ In this specification we find a clear and precisely measured relationship between health status and portfolio allocation: a one-percentage point increase in self-reported health (ranked 1-5, with $5=$ poor) is associated with about a 0.75 percent reduction in the stock share of financial wealth for younger households and about a 0.35 percent reduction in the stock share for older households. These findings are lower than those in Rosen and Wu's estimates of 1-2 percentage points, but they imply a similarly large adjustment when we account for the fact that Rosen and $\mathrm{Wu}$ use an indicator for poor health, rather than a categorical variable. ${ }^{24}$

We also find a positive relationship between OOP expenses and the stock share. A mechanical explanation for this relationship is that some households may be reluctant to finance out-of-pocket expenses out of stocks and choose instead to pay for them out of safe assets. In this case, the share of stock could rise even if the total value of stocks remains unchanged. In addition, this result might be related to the discretionary nature of some medical costs: if households can choose different levels of medical care, high out-of-pocket medical expenses might be correlated with unobserved shocks to future income and nonmedical expenses. ${ }^{25}$

But again, we must take care not to impose a causal gloss on these results if we suspect correlation between the unobserved random effect and observables. In the correlated random effects specification, shown in the middle panel of Table 6 , we find that self-reported health is still negatively correlated with stock share for younger households, but the estimated marginal effect is about 25 percent lower. As with the case of the ownership regressions, we find essentially no correlation among older households. In addition, the strong, positive

\footnotetext{
${ }^{23}$ Again, see Table 7 for estimates for the full sample, unconditional on age.

${ }^{24}$ When we estimate our equations using their indicator variable for health, we estimate the coefficient on self-reported health to be about 1 percent.

${ }^{25} \mathrm{~A}$ related issue concerns accidental portfolio rebalancing due to fluctuations in the stock market. Because of trading costs and other frictions, households may not continuously rebalance their portfolios in response to market fluctuations (see, e.g., Liu (2004)). Nevertheless, as long as health shocks cause some households to hit their decision threshold, we should still be able to pick up such a relationship in our empirical estimates.
} 
coefficent estimates on out-of-pocket expenses found in the baseline random effects specification vanish once we allow for correlated random effects. This is what we might expect since it would be surprising if higher out-of-pocket medical costs actually led to increased stock exposure. Thus, we find that much of the correlation between health and portfolio allocation seems to be due to unobserved heterogeneity rather than to represent a causal link.

The right-hand panels show the results for the fixed-effect specification. Again we find that the fixed effects specification attenuates both the magnitude and statistical significance of the coefficient estimates. The loss of significance may be driven partly by the tendency for measurement error in the explanatory variables to increase the noise-to-signal ratio in a fixed effect regression. Attenuation bias due to measurement error is typically exacerbated in the fixed effects framework. Because the fixed effects estimator only uses information about changes in variables within observations, it tends to decrease the signal-to-noise ratio and therefore the reliability associated with each coefficient estimate. Nevertheless, because we do find significant fixed effects estimates for younger households, measurement error is unlikely to be the sole explanation for the statistically insignificant and small estimates for older households.

One interpretation of these results is that while health may be useful for explaining differences across individuals and households, it exerts no obvious influence on portfolio decisions for older households over time. An alternative explanation is that health matters for portfolio choice, but that the effect is not contemporaneous with the change in health status. For example, individuals currently in poor (or good) health may have adjusted their portfolios the moment - potentially years in the past - that they learned of their expected health outcomes. Alternatively, it may take households a long time to adjust to health shocks. Although the expectation or lagged-response stories are possible, it seems somewhat of a stretch considering that the HRS waves are two years apart. For these stories to be materially affecting our results, household expectations or lagged responses would have to take place more than two years in advance of, or following, the health shock.

Two main messages emerge from the results from these findings. First, failing to account for unobserved heterogeneity can generate biased estimates of the effect of health on portfolio choice. Most dramatically, this can be seen in the vanishing significance of out-of-pocket medical costs when we move to the correlated random effects and fixed effects specifications. Second, by controlling for unobserved heterogeneity, we also learn that the connection between health and portfolio choice depends critically on the age of the households. Younger households show a small response to health on both the intensive and extensive margins, while older households do not. 


\section{Conclusion}

We test whether the relationship between health and portfolio choice persists after accounting carefully for the effects of unobserved heterogeneity, and we find that it does, at a reduced level, for younger households. For older households, we find no evidence that health operates on either the extensive margin of stock ownership or on the intensive margin of asset allocation. Once we account for unobserved effects through a correlated random effects model or a fixed effects estimator, the estimates on the health variables for older households become small and statistically insignificant. One explanation for this result is that health and portfolio choice are unrelated for older households. However, there are other possible explanations, including measurement error in the health variables, the role of expectations, and heterogeneity across similar households in the relationship between health and portfolios.

Finally, our results could be reflecting the ambiguous relationship between health and portfolio choice. Theoretically, the effect of health on allocation decisions depends on how health affects the marginal utility of consumption. Since this derivative can plausibly take either a positive or a negative sign, the net effect of health is ambiguous - some households

might respond to worsening health by increasing their stock share, while others might move toward safer assets. Or, if the opposing forces of health on desired consumption affect each household's utility in the same way, our finding could reflect genuine ambivalence at the household level.

No matter what the interpretation, though, our findings indicate that the empirical relationship between health and portfolio choice is far less clear than previous studies suggest. If such a relationship exists, it appears to operate largely for younger households and with a small overall effect. 


\section{References}

Alan, S., and S. Leth-Petersen (2006): "Tax Incentives and Household Portfolios: A Panel Data Analysis," CAM Working Paper 2006-13.

BAkiJA, J. (2004): "The Effect of Taxes on Portfolio Choice: Evidence from Panel Data Spanning the Tax Reform Act of 1986," Manuscript.

Berkowitz, M. K., And J. Qiu (2006): "A Further Look at Household Portfolio Choice and Health Status," The Journal of Banking and Finance, 30, 1201-1217.

Bodie, Z., R. C. Merton, and W. F. Samuelson (1992): "Labor Flexibility and Porfolio Choice in a Life Cycle Model," Journal of Economic Dynamics and Control, 16, 427-449.

Bound, J., C. Brown, and N. Mathiowetz (2001): "Measurement Error in Survey Data," in Handbook of Econometrics, ed. by J. Heckman, and E. Leamer, pp. 3705-3843. North-Holland, Amsterdam.

Chamberlain, G. (1980): "Analysis of Covariance with Qualitative Data," Review of Economic Studies, 47, 225-238.

Chamberlain, G. (1984): "Panel Data," in Handbook of Econometrics, ed. by Z. Griliches, and M. Intrilligator, chap. Panel Data, pp. 1247-1318. North-Holland, Amsterdam.

Christelis, D., T. Jappelli, and M. Padula (2006): "Cognitive Abilities and Portfolio Choice," CSEF Working Paper No. 157.

Coile, C., and K. Milligan (2006): "How Household Portfolios Evolve After Retirement: The Effect of Aging and Health Shocks," NBER Working Paper No. 12391.

EDwards, R. D. (2006): "Health Shocks and Consumption Among Elderly U.S. Households," Manuscript.

(2007): "Optimal Portfolio Choice Under State-Dependent Utility," Manuscript.

— (forthcoming): "Health Risk and Portfolio Choice," forthcoming in Journal of Business and Economic Statistics.

French, E., And J. B. Jones (2004): "On the Distribution and Dynamics of Health Care Costs," Journal of Applied Econometrics, 19, 705-721.

Gilbert, D. (2006): Stumbling on Happiness. Knopf, New York.

Heckman, J. J. (1979): "Sample Selection Bias as a Specification Error," Econometrica, $47(1), 153-161$.

Hochguertel, S. (2003): "Precautionary Motives and Portfolio Decisions," Journal of Applied Econometrics, 18, 61-77.

Honoré, B. E. (1992): "Trimmed LAD and Least Squares Estimation of Truncated and Censored Regression Models with Fixed Effects," Econometrica, 60(3), 533-565. 
Honoré, B. E., and S. Leth-Petersen (2006): "Estimation of Panel Data Models with Two-sided Censoring," Manuscript.

Hubbard, R. G., J. Skinner, and S. P. Zeldes (1995): "Precautionary Saving and Social Insurance," Journal of Political Economy, 103(2), 360-399.

Kyriazidou, E. (1997): "Estimation of a Panel Data Sample Selection Model," Econometrica, 65(6), 1335-1364.

LiU, H. (2004): "Optimal Consumption and Investment with Transaction Costs and Multiple Risky Assets," The Journal of Finance, 59(1), 289-338.

Michaud, P.-C., And A. VAn Soest (2008): "Health and Wealth of Elderly Couples: Health and Wealth of Elderly Couples: Causality Tests Using Dynamic Panel Data Models," forthcoming in Journal of Health Economics.

Pang, G., and M. J. Warshawsky (2008): "Optimizing the Equity-Bond-Annuity Portfolio in Retirement: The Impact of Uncertain Health Expenses," Pension Research Council WP, 2008-05.

Rosen, H. S., And S. Wu (2004): "Portfolio Choice and Health Status," Journal of Financial Economics, 72, 457-484.

van Soest, A., And A. Kapetyn (2006): "Savings, Portfolio Choice, and Retirement Expectations," University of Michigan Retirement Research Center WP 2006-119. 


\section{Tables and Figures}

Table 1: Demographics in 1998

\begin{tabular}{lrrr}
\hline \hline Variable & Age $<70$ & Age $\geq 70$ & All \\
\hline Age & 59 & 78 & 66 \\
Married & .55 & .38 & .49 \\
Single Female & .29 & .47 & .36 \\
Single Male & .16 & .14 & .15 \\
High School & .55 & .51 & .52 \\
College & .28 & .17 & .20 \\
Nonwhite & .17 & .11 & .14 \\
Hispanic & .08 & .05 & .06 \\
Number of Children & 3.0 & 2.9 & 3.0 \\
Sample Size & 7,824 & 5,879 & 13,703 \\
\hline
\end{tabular}

Means calculated using HRS sample weights.

Table 2: Mean Household Wealth and Portfolio Shares

\begin{tabular}{lrrrrr}
\hline \hline Variable & 1998 & 2000 & 2002 & 2004 & 2006 \\
\hline Age $<70$ in 1998 & & & & & \\
Financial Wealth & 100.6 & 105.1 & 107.0 & 164.6 & 162.3 \\
Retirement Accounts & 107.5 & 96.3 & 98.7 & 115.2 & 172.3 \\
Nonfinancial Wealth & 221.3 & 206.1 & 259.0 & 291.3 & 373.1 \\
Owns Stocks in FW & .320 & .309 & .290 & .268 & .224 \\
Stock Share of FW & .218 & .237 & .235 & .205 & .172 \\
& & & & & \\
Age $\geq$ 70 in 1998 & & & & & \\
Financial Wealth & 134.9 & 122.2 & 139.9 & 157.0 & 168.5 \\
Retirement Accounts & 35.6 & 34.7 & 31.0 & 32.0 & 28.8 \\
Nonfinancial Wealth & 168.6 & 147.0 & 181.2 & 194.1 & 255.1 \\
Owns Stocks in FW & .306 & .282 & .235 & .205 & .172 \\
Stock Share of FW & .194 & .208 & .194 & .200 & .194 \\
\hline
\end{tabular}

Means are calculated using HRS sample weights. Wealth values are in thousands and reported in 2006 dollars. 
Table 3: Means of Health Measures

\begin{tabular}{lrrrrr}
\hline \hline Variable & 1998 & 2000 & 2002 & 2004 & 2006 \\
\hline Age $<70$ in 1998 & & & & & \\
Self-reported Health Status $^{1}$ & 3.00 & 2.92 & 3.00 & 3.08 & 3.10 \\
Number of Diagnosed Conditions $^{2}$ & 1.62 & 1.83 & 2.08 & 2.32 & 2.56 \\
Mean OOP Medical Expense $^{3}$ & 2,758 & 2,975 & 4,796 & 5,932 & 4,948 \\
& & & & & \\
Age $\geq 70$ in 1998 & & & & \\
Self-reported Health Status $^{1}$ & 3.30 & 3.21 & 3.28 & 3.27 & 3.29 \\
Number of Diagnosed Conditions $^{2}$ & 2.22 & 2.38 & 2.60 & 2.74 & 2.92 \\
Mean OOP Medical Expense $^{3}$ & 3,178 & 4,030 & 6,474 & 7,966 & 7,021 \\
\hline
\end{tabular}

${ }^{1}$ Index from $1=$ Excellent to $5=$ Poor .

${ }^{2}$ Number of following conditions: high BP, diabetes, cancer, lung disease, heart problems, stroke, psych. problems, arthritis.

${ }^{3}$ Out-of-pocket medical expenses, in real 2006 dollars.

Table 4: Stock Allocation and Ownership by Health Status

\begin{tabular}{|c|c|c|c|c|}
\hline \multirow[b]{2}{*}{ Variable } & \multicolumn{2}{|c|}{ Allocation } & \multicolumn{2}{|c|}{ Ownership } \\
\hline & Age $<70$ & Age $\geq 70$ & Age $<70$ & Age $\geq 70$ \\
\hline \multicolumn{5}{|l|}{ Self-reported Health Status } \\
\hline Excellent or Very Good & .259 & .243 & .422 & .391 \\
\hline Good & .206 & .207 & .320 & .336 \\
\hline Fair or Poor & .134 & .155 & .177 & .232 \\
\hline \multicolumn{5}{|c|}{ Number of Diagnosed Conditions } \\
\hline None & .235 & .211 & .364 & .333 \\
\hline One to Three & .196 & .204 & .296 & .324 \\
\hline Four to Eight & .127 & .164 & .176 & .247 \\
\hline \multicolumn{5}{|c|}{ Out of Pocket Medical Expenses } \\
\hline Lower Third & .165 & .143 & .229 & .204 \\
\hline Middle Third & .224 & .205 & .347 & .338 \\
\hline Upper Third & .224 & .230 & .358 & .372 \\
\hline
\end{tabular}

Allocation measures share of financial assets allocated to stock. Ownership measures probability of owning any stock. Means calculated using HRS sample weights. 
Table 5: Stock Ownership Estimates

\begin{tabular}{|c|c|c|c|c|c|c|}
\hline \multirow[b]{2}{*}{ Explanatory Variable } & \multicolumn{2}{|c|}{$\underline{\mathbf{R E}}$} & \multicolumn{2}{|c|}{ CRE } & \multicolumn{2}{|c|}{$\underline{F E}$} \\
\hline & Age $<70$ & Age $\geq 70$ & Age $<70$ & Age $\geq 70$ & Age $<70$ & Age $\geq 70$ \\
\hline Self-reported health & $\begin{array}{c}-0.075^{* * *} \\
(0.016)\end{array}$ & $\begin{array}{l}-0.032 \\
(0.020)\end{array}$ & $\begin{array}{c}-0.046^{*} \\
(0.022)\end{array}$ & $\begin{array}{c}0.025 \\
(0.025)\end{array}$ & $\begin{array}{c}-0.083^{*} \\
(0.040)\end{array}$ & $\begin{array}{c}0.048 \\
(0.049)\end{array}$ \\
\hline Log OOP med costs & $\begin{array}{c}0.026^{* *} \\
(0.008)\end{array}$ & $\begin{array}{c}0.042^{* * *} \\
(0.010)\end{array}$ & $\begin{array}{c}0.003 \\
(0.011)\end{array}$ & $\begin{array}{c}0.013 \\
(0.012)\end{array}$ & $\begin{array}{l}-0.003 \\
(0.020)\end{array}$ & $\begin{array}{c}0.034 \\
(0.024)\end{array}$ \\
\hline Prob. leave beq & $\begin{array}{c}0.380^{* * *} \\
(0.045)\end{array}$ & $\begin{array}{c}0.318^{* * *} \\
(0.054)\end{array}$ & $\begin{array}{l}0.123^{*} \\
(0.059)\end{array}$ & $\begin{array}{c}0.130 \\
(0.067)\end{array}$ & $\begin{array}{c}0.163 \\
(0.106)\end{array}$ & $\begin{array}{c}0.246 \\
(0.126)\end{array}$ \\
\hline Health insurance & $\begin{array}{c}0.029 \\
(0.058)\end{array}$ & $\begin{array}{c}0.112 \\
(0.192)\end{array}$ & $\begin{array}{c}0.012 \\
(0.071)\end{array}$ & $\begin{array}{c}0.200 \\
(0.212)\end{array}$ & $\begin{array}{l}-0.000 \\
(0.129)\end{array}$ & $\begin{array}{c}0.667 \\
(0.415)\end{array}$ \\
\hline Log net fin assets & $\begin{array}{c}0.449^{* * *} \\
(0.011)\end{array}$ & $\begin{array}{c}0.644^{* * *} \\
(0.017)\end{array}$ & $\begin{array}{c}0.318^{* * *} \\
(0.015)\end{array}$ & $\begin{array}{c}0.487^{* * *} \\
(0.019)\end{array}$ & $\begin{array}{c}0.538^{* * *} \\
(0.028)\end{array}$ & $\begin{array}{c}0.783^{* * *} \\
(0.039)\end{array}$ \\
\hline Log non-fin wealth & $\begin{array}{c}0.023^{* * *} \\
(0.006)\end{array}$ & $\begin{array}{c}0.024^{* *} \\
(0.007)\end{array}$ & $\begin{array}{c}0.002 \\
(0.007)\end{array}$ & $\begin{array}{l}-0.002 \\
(0.010)\end{array}$ & $\begin{array}{l}-0.003 \\
(0.013)\end{array}$ & $\begin{array}{c}0.003 \\
(0.019)\end{array}$ \\
\hline Log income, exl. cap gains & $\begin{array}{c}0.009 \\
(0.007)\end{array}$ & $\begin{array}{c}0.008 \\
(0.025)\end{array}$ & $\begin{array}{l}0.020^{*} \\
(0.008)\end{array}$ & $\begin{array}{l}-0.019 \\
(0.029)\end{array}$ & $\begin{array}{l}0.037^{*} \\
(0.015)\end{array}$ & $\begin{array}{l}-0.054 \\
(0.054)\end{array}$ \\
\hline Single male & $\begin{array}{c}0.032 \\
(0.057)\end{array}$ & $\begin{array}{c}0.016 \\
(0.068)\end{array}$ & $\begin{array}{c}0.053 \\
(0.103)\end{array}$ & $\begin{array}{l}-0.031 \\
(0.100)\end{array}$ & $\begin{array}{c}0.048 \\
(0.191)\end{array}$ & $\begin{array}{l}-0.129 \\
(0.192)\end{array}$ \\
\hline Single female & $\begin{array}{l}-0.024 \\
(0.048)\end{array}$ & $\begin{array}{l}0.142^{*} \\
(0.061)\end{array}$ & $\begin{array}{l}-0.076 \\
(0.117)\end{array}$ & $\begin{array}{c}0.117 \\
(0.117)\end{array}$ & $\begin{array}{l}-0.157 \\
(0.218)\end{array}$ & $\begin{array}{c}0.157 \\
(0.218)\end{array}$ \\
\hline Age & $\begin{array}{c}0.002 \\
(0.004)\end{array}$ & $\begin{array}{c}0.015^{* * *} \\
(0.004)\end{array}$ & & & & \\
\hline Any children & $\begin{array}{c}0.068 \\
(0.064)\end{array}$ & $\begin{array}{l}-0.034 \\
(0.085)\end{array}$ & $\begin{array}{c}0.092 \\
(0.066)\end{array}$ & $\begin{array}{c}0.006 \\
(0.089)\end{array}$ & & \\
\hline High school & $\begin{array}{c}0.435^{* * *} \\
(0.066)\end{array}$ & $\begin{array}{c}0.537^{* * *} \\
(0.073)\end{array}$ & $\begin{array}{c}0.340^{* * *} * \\
(0.069)\end{array}$ & $\begin{array}{c}0.363^{* * *} \\
(0.077)\end{array}$ & & \\
\hline College & $\begin{array}{c}0.751^{* * *} \\
(0.074)\end{array}$ & $\begin{array}{c}1.021^{* * *} \\
(0.090)\end{array}$ & $\begin{array}{c}0.545^{* * *} \\
(0.078)\end{array}$ & $\begin{array}{c}0.693^{* * *} \\
(0.097)\end{array}$ & & \\
\hline Nonwhite & $\begin{array}{c}-0.362^{* * *} \\
(0.058)\end{array}$ & $\begin{array}{c}-0.381^{* * *} \\
(0.110)\end{array}$ & $\begin{array}{c}-0.241^{* * *} \\
(0.060)\end{array}$ & $\begin{array}{l}-0.146 \\
(0.117)\end{array}$ & & \\
\hline Hispanic & $\begin{array}{c}-0.588^{* * *} \\
(0.096)\end{array}$ & $\begin{array}{c}-0.968^{* * *} \\
(0.188)\end{array}$ & $\begin{array}{c}-0.537^{* * *} \\
(0.100)\end{array}$ & $\begin{array}{c}-0.833^{* * *} \\
(0.199)\end{array}$ & & \\
\hline Receiving Soc Sec & $\begin{array}{c}0.021 \\
(0.041)\end{array}$ & $\begin{array}{c}0.032 \\
(0.086)\end{array}$ & $\begin{array}{c}0.024 \\
(0.035)\end{array}$ & $\begin{array}{c}0.088 \\
(0.088)\end{array}$ & $\begin{array}{l}-0.057 \\
(0.090)\end{array}$ & $\begin{array}{c}0.108 \\
(0.223)\end{array}$ \\
\hline Year: 2000 & $\begin{array}{c}0.045 \\
(0.036)\end{array}$ & $\begin{array}{l}0.116^{*} \\
(0.048)\end{array}$ & $\begin{array}{c}0.051 \\
(0.036)\end{array}$ & $\begin{array}{l}0.103^{*} \\
(0.049)\end{array}$ & $\begin{array}{c}0.058 \\
(0.069)\end{array}$ & $\begin{array}{c}0.166 \\
(0.092)\end{array}$ \\
\hline Year: 2002 & $\begin{array}{l}-0.057 \\
(0.039)\end{array}$ & $\begin{array}{l}-0.124^{*} \\
(0.049)\end{array}$ & $\begin{array}{l}-0.037 \\
(0.039)\end{array}$ & $\begin{array}{l}-0.121^{*} \\
(0.050)\end{array}$ & $\begin{array}{l}-0.052 \\
(0.074)\end{array}$ & $\begin{array}{l}-0.194^{*} \\
(0.097)\end{array}$ \\
\hline Year: 2004 & $\begin{array}{c}-0.157^{* * *} \\
(0.039)\end{array}$ & $\begin{array}{l}-0.123^{*} \\
(0.051)\end{array}$ & $\begin{array}{c}-0.122^{* *} \\
(0.039)\end{array}$ & $\begin{array}{l}-0.117^{*} \\
(0.053)\end{array}$ & $\begin{array}{l}-0.176^{*} \\
(0.082)\end{array}$ & $\begin{array}{l}-0.165 \\
(0.103)\end{array}$ \\
\hline Year: 2006 & $\begin{array}{c}-0.367^{* * *} \\
(0.043)\end{array}$ & $\begin{array}{c}-0.396^{* * *} \\
(0.053)\end{array}$ & $\begin{array}{c}-0.342^{* * *} \\
(0.043)\end{array}$ & $\begin{array}{c}-0.403^{* * *} \\
(0.055)\end{array}$ & $\begin{array}{c}-0.546^{* * *} \\
(0.091)\end{array}$ & $\begin{array}{c}-0.619^{* * *} \\
(0.109)\end{array}$ \\
\hline Constant & $\begin{array}{c}-6.626^{* * *} \\
(0.297)\end{array}$ & $\begin{array}{c}-10.215^{* * *} \\
(0.519)\end{array}$ & $\begin{array}{c}-7.824^{* * *} \\
(0.283)\end{array}$ & $\begin{array}{c}-10.982^{* * *} \\
(0.649)\end{array}$ & & \\
\hline $\begin{array}{l}\text { Avg. marg. effect/coeff } \\
\mathrm{N}\end{array}$ & $\begin{array}{c}0.274 \\
24,315\end{array}$ & $\begin{array}{c}0.220 \\
20,403\end{array}$ & $\begin{array}{c}0.266 \\
24,315\end{array}$ & $\begin{array}{c}0.200 \\
20,403\end{array}$ & 8,125 & 5,624 \\
\hline
\end{tabular}

Notes: This table reports the coefficient estimates and standard errors (in parentheses) for random effects (RE) and correlated random effects (CRE) probit and fixed effects (FE) logit specifications. The dependent variable is an indicator variable for whether the household owns a positive amount of stocks outside of retirement accounts. Avg. marg. effect/coeff is the average ratio of the marginal effect to the coefficient estimate. Self-reported health $(1-5$, with $5=$ poor $)$ is the maximum reported value within a household. Prob. leave beq is the self-reported probability of leaving a bequest of at least $\$ 100,000$. Age is the maximum age within the household. Receiving Soc Sec is an indicator for whether the household receives at least $\$ 1,000$ of Social Security retirement benefits. 1998-2006 waves of the HRS. Values converted to 2006 dollars using the CPI-U. Statistical significance is indicated as follows: ${ }^{*} p<0.05,{ }^{* *} p<0.01,{ }^{* * *} p<0.001$. 
Table 6: Stock Allocation Estimates

\begin{tabular}{|c|c|c|c|c|c|c|}
\hline \multirow[b]{2}{*}{ Explanatory Variable } & \multicolumn{2}{|c|}{$\underline{\mathbf{R E}}$} & \multicolumn{2}{|c|}{ CRE } & \multicolumn{2}{|c|}{$\underline{\text { FE }}$} \\
\hline & Age $<70$ & Age $\geq 70$ & Age $<70$ & Age $\geq 70$ & Age $<70$ & Age $\geq 70$ \\
\hline Self-reported health & $\begin{array}{c}-0.025^{* * *} \\
(0.006)\end{array}$ & $\begin{array}{c}-0.012^{*} \\
(0.005)\end{array}$ & $\begin{array}{c}-0.019^{*} \\
(0.008)\end{array}$ & $\begin{array}{c}0.002 \\
(0.007)\end{array}$ & $\begin{array}{l}-0.020 \\
(0.010)\end{array}$ & $\begin{array}{l}-0.009 \\
(0.008)\end{array}$ \\
\hline Log OOP med costs & $\begin{array}{c}0.009 * * \\
(0.003)\end{array}$ & $\begin{array}{c}0.011^{* * *} \\
(0.003)\end{array}$ & $\begin{array}{c}-0.000 \\
(0.004)\end{array}$ & $\begin{array}{c}0.002 \\
(0.003)\end{array}$ & $\begin{array}{l}-0.006 \\
(0.005)\end{array}$ & $\begin{array}{c}0.000 \\
(0.005)\end{array}$ \\
\hline Prob. leave beq & $\begin{array}{c}0.115^{* * *} \\
(0.016)\end{array}$ & $\begin{array}{c}0.070^{* * *} \\
(0.015)\end{array}$ & $\begin{array}{c}0.018 \\
(0.021)\end{array}$ & $\begin{array}{c}0.006 \\
(0.018)\end{array}$ & $\begin{array}{l}-0.004 \\
(0.033)\end{array}$ & $\begin{array}{l}-0.008 \\
(0.026)\end{array}$ \\
\hline Health insurance & $\begin{array}{c}0.012 \\
(0.021)\end{array}$ & $\begin{array}{c}0.061 \\
(0.055)\end{array}$ & $\begin{array}{c}0.009 \\
(0.025)\end{array}$ & $\begin{array}{c}0.069 \\
(0.059)\end{array}$ & & \\
\hline Log net fin assets & $\begin{array}{c}0.170^{* * *} \\
(0.004)\end{array}$ & $\begin{array}{c}0.187^{* * *} \\
(0.004)\end{array}$ & $\begin{array}{c}0.122^{* * *} \\
(0.005)\end{array}$ & $\begin{array}{c}0.140^{* * *} \\
(0.005)\end{array}$ & $\begin{array}{c}0.152 \\
(0.010)\end{array}$ & $\begin{array}{c}0.162 \\
(0.009)\end{array}$ \\
\hline Log non-fin wealth & $\begin{array}{c}0.006^{* *} \\
(0.002)\end{array}$ & $\begin{array}{c}0.005^{* *} \\
(0.002)\end{array}$ & $\begin{array}{c}-0.002 \\
(0.003)\end{array}$ & $\begin{array}{l}-0.001 \\
(0.003)\end{array}$ & $\begin{array}{l}-0.004 \\
(0.005)\end{array}$ & $\begin{array}{c}0.000 \\
(0.005)\end{array}$ \\
\hline Log income, exl. cap gains & $\begin{array}{c}0.003 \\
(0.002)\end{array}$ & $\begin{array}{l}-0.005 \\
(0.007)\end{array}$ & $\begin{array}{l}0.006^{*} \\
(0.003)\end{array}$ & $\begin{array}{l}-0.012 \\
(0.008)\end{array}$ & $\begin{array}{c}0.007 \\
(0.003)\end{array}$ & $\begin{array}{l}-0.025 \\
(0.012)\end{array}$ \\
\hline Single male & $\begin{array}{c}0.036 \\
(0.021)\end{array}$ & $\begin{array}{c}0.011 \\
(0.019)\end{array}$ & $\begin{array}{c}0.059 \\
(0.036)\end{array}$ & $\begin{array}{c}-0.004 \\
(0.026)\end{array}$ & $\begin{array}{c}0.068 \\
(0.057)\end{array}$ & $\begin{array}{l}-0.033 \\
(0.039)\end{array}$ \\
\hline Single female & $\begin{array}{l}-0.008 \\
(0.018)\end{array}$ & $\begin{array}{l}0.036^{*} \\
(0.017)\end{array}$ & $\begin{array}{l}-0.056 \\
(0.041)\end{array}$ & $\begin{array}{c}0.018 \\
(0.032)\end{array}$ & $\begin{array}{l}-0.081 \\
(0.052)\end{array}$ & $\begin{array}{l}-0.011 \\
(0.051)\end{array}$ \\
\hline Age & $\begin{array}{l}-0.001 \\
(0.001)\end{array}$ & $\begin{array}{c}0.004^{* *} \\
(0.001)\end{array}$ & & & & \\
\hline Any children & $\begin{array}{c}0.045 \\
(0.023)\end{array}$ & $\begin{array}{c}0.003 \\
(0.024)\end{array}$ & $\begin{array}{l}0.052^{*} \\
(0.024)\end{array}$ & $\begin{array}{c}0.016 \\
(0.025)\end{array}$ & & \\
\hline High school & $\begin{array}{c}0.173^{* * *} \\
(0.025)\end{array}$ & $\begin{array}{c}0.167^{* * *} \\
(0.022)\end{array}$ & $\begin{array}{c}0.138^{* * *} \\
(0.025)\end{array}$ & $\begin{array}{c}0.104^{* * *} \\
(0.023)\end{array}$ & & \\
\hline College & $\begin{array}{c}0.264^{* * *} \\
(0.027)\end{array}$ & $\begin{array}{c}0.306^{* * *} \\
(0.026)\end{array}$ & $\begin{array}{c}0.189^{* * *} \\
(0.028)\end{array}$ & $\begin{array}{c}0.187^{* * *} \\
(0.028)\end{array}$ & & \\
\hline Nonwhite & $\begin{array}{c}-0.104^{* * *} \\
(0.022)\end{array}$ & $\begin{array}{c}-0.122^{* * *} \\
(0.033)\end{array}$ & $\begin{array}{c}-0.059^{* *} \\
(0.022)\end{array}$ & $\begin{array}{c}-0.041 \\
(0.034)\end{array}$ & & \\
\hline Hispanic & $\begin{array}{c}-0.204^{* * *} \\
(0.036)\end{array}$ & $\begin{array}{c}-0.255^{* * *} \\
(0.056)\end{array}$ & $\begin{array}{c}-0.180^{* * *} \\
(0.037)\end{array}$ & $\begin{array}{c}-0.202^{* * *} \\
(0.058)\end{array}$ & & \\
\hline Receiving Soc Sec & $\begin{array}{c}0.007 \\
(0.014)\end{array}$ & $\begin{array}{l}-0.008 \\
(0.024)\end{array}$ & $\begin{array}{c}0.002 \\
(0.012)\end{array}$ & $\begin{array}{c}0.005 \\
(0.024)\end{array}$ & & \\
\hline Year: 2000 & $\begin{array}{l}0.027^{*} \\
(0.012)\end{array}$ & $\begin{array}{l}0.031^{*} \\
(0.013)\end{array}$ & $\begin{array}{l}0.028^{*} \\
(0.012)\end{array}$ & $\begin{array}{c}0.029 * \\
(0.013)\end{array}$ & $\begin{array}{c}0.046 \\
(0.015)\end{array}$ & $\begin{array}{c}0.031 \\
(0.016)\end{array}$ \\
\hline Year: 2002 & $\begin{array}{l}-0.025 \\
(0.013)\end{array}$ & $\begin{array}{c}-0.021 \\
(0.013)\end{array}$ & $\begin{array}{l}-0.018 \\
(0.013)\end{array}$ & $\begin{array}{c}-0.018 \\
(0.013)\end{array}$ & $\begin{array}{l}-0.011 \\
(0.017)\end{array}$ & $\begin{array}{c}0.006 \\
(0.017)\end{array}$ \\
\hline Year: 2004 & $\begin{array}{c}-0.062^{* * *} \\
(0.013)\end{array}$ & $\begin{array}{l}-0.020 \\
(0.014)\end{array}$ & $\begin{array}{c}-0.049^{* * *} \\
(0.013)\end{array}$ & $\begin{array}{l}-0.015 \\
(0.014)\end{array}$ & $\begin{array}{l}-0.045 \\
(0.019)\end{array}$ & $\begin{array}{c}0.011 \\
(0.018)\end{array}$ \\
\hline Year: 2006 & $\begin{array}{c}-0.130^{* * *} \\
(0.015)\end{array}$ & $\begin{array}{c}-0.077^{* * *} \\
(0.014)\end{array}$ & $\begin{array}{c}-0.118^{* * *} \\
(0.015)\end{array}$ & $\begin{array}{c}-0.073^{* * *} \\
(0.014)\end{array}$ & $\begin{array}{c}-0.108 \\
(0.020)\end{array}$ & $\begin{array}{l}-0.027 \\
(0.020)\end{array}$ \\
\hline Constant & $-2.388^{* * *}$ & $-2.853^{* * *}$ & $-2.811^{* * *}$ & $-3.109^{* * *}$ & & \\
\hline Avg. marg. effect/coeff & 0.3000 & 0.2849 & 0.2964 & 0.2746 & & \\
\hline $\mathrm{N}$ & 23,665 & 20,173 & 23,665 & 20,173 & 21,359 & 18,097 \\
\hline
\end{tabular}

Notes: This table reports the coefficient estimates and standard errors (in parentheses) for random effects (RE), correlated random effects (CRE), and fixed effects (FE) Tobit specifications (see Honoré and LethPetersen 2006 for censored fixed effects method). The dependent variable is the financial wealth share of stocks held outside of retirement accounts. Avg. marg. effect/coeff is the average ratio of the marginal effects to the coefficient estimates. Self-reported health $(1-5$, with $5=$ poor $)$ is the maximum reported value within a household. Prob. leave beq is the self-reported probability of leaving a bequest of at least $\$ 100,000$. Age is the maximum age within the household. Receiving Soc Sec is an indicator for whether the household receives at least $\$ 1,000$ of Social Security retirement benefits. 1998-2006 waves of the HRS. Values converted to 2006 dollars using the CPI-U. Statistical significance is indicated as follows: ${ }^{*} p<0.05,{ }^{* *} p<0.01,{ }^{* * *}$ $p<0.001$. 
Table 7: Ownership and Allocation Estimates for Full Sample

\begin{tabular}{|c|c|c|c|c|c|c|}
\hline \multirow[b]{2}{*}{ Explanatory Variable } & \multicolumn{3}{|c|}{ Ownership } & \multicolumn{3}{|c|}{ Allocation } \\
\hline & RE & CRE & FE & CRE & $\mathbf{R E}$ & FE \\
\hline Self-reported health & $\begin{array}{c}-0.055^{* * *} \\
(0.013)\end{array}$ & $\begin{array}{l}-0.016 \\
(0.016)\end{array}$ & $\begin{array}{c}-0.036 \\
(0.030)\end{array}$ & $\begin{array}{c}-0.018^{* * *} \\
(0.004)\end{array}$ & $\begin{array}{l}-0.007 \\
(0.005)\end{array}$ & $\begin{array}{l}-0.009 \\
(0.006)\end{array}$ \\
\hline Log OOP med costs & $\begin{array}{c}0.030^{* * *} \\
(0.006)\end{array}$ & $\begin{array}{c}0.005 \\
(0.008)\end{array}$ & $\begin{array}{c}0.006 \\
(0.015)\end{array}$ & $\begin{array}{c}0.010^{* * *} \\
(0.002)\end{array}$ & $\begin{array}{c}0.000 \\
(0.002)\end{array}$ & $\begin{array}{l}-0.004 \\
(0.003)\end{array}$ \\
\hline Prob. leave beq & $\begin{array}{c}0.357^{* * *} \\
(0.034)\end{array}$ & $\begin{array}{c}0.121^{* *} \\
(0.043)\end{array}$ & $\begin{array}{c}0.216^{* *} \\
(0.077)\end{array}$ & $\begin{array}{c}0.096^{* * *} \\
(0.011)\end{array}$ & $\begin{array}{c}0.014 \\
(0.014)\end{array}$ & $\begin{array}{l}-0.008 \\
(0.019)\end{array}$ \\
\hline Health insurance & $\begin{array}{c}0.012 \\
(0.058)\end{array}$ & $\begin{array}{c}0.022 \\
(0.068)\end{array}$ & $\begin{array}{c}-0.006 \\
(0.122)\end{array}$ & $\begin{array}{c}0.010 \\
(0.019)\end{array}$ & $\begin{array}{c}0.011 \\
(0.022)\end{array}$ & \\
\hline Log net fin assets & $\begin{array}{c}0.515^{* * *} \\
(0.009)\end{array}$ & $\begin{array}{c}0.381^{* * *} \\
(0.011)\end{array}$ & $\begin{array}{c}0.635^{* * *} \\
(0.022)\end{array}$ & $\begin{array}{c}0.175^{* * *} \\
(0.003)\end{array}$ & $\begin{array}{c}0.131^{* * *} \\
(0.004)\end{array}$ & $\begin{array}{c}0.160 \\
(0.006)\end{array}$ \\
\hline Log non-fin wealth & $\begin{array}{c}0.020 * * * \\
(0.004)\end{array}$ & $\begin{array}{l}-0.000 \\
(0.006)\end{array}$ & $\begin{array}{l}-0.000 \\
(0.010)\end{array}$ & $\begin{array}{c}0.005^{* *} \\
(0.001)\end{array}$ & $\begin{array}{l}-0.002 \\
(0.002)\end{array}$ & $\begin{array}{c}0.000 \\
(0.003)\end{array}$ \\
\hline Log income, exl. cap gains & $\begin{array}{c}0.012 \\
(0.007)\end{array}$ & $\begin{array}{l}0.018^{*} \\
(0.008)\end{array}$ & $\begin{array}{l}0.031^{*} \\
(0.014)\end{array}$ & $\begin{array}{c}0.003 \\
(0.002)\end{array}$ & $\begin{array}{c}0.005 \\
(0.002)\end{array}$ & $\begin{array}{c}0.005 \\
(0.003)\end{array}$ \\
\hline Single male & $\begin{array}{c}0.024 \\
(0.044)\end{array}$ & $\begin{array}{l}-0.002 \\
(0.068)\end{array}$ & $\begin{array}{l}-0.055 \\
(0.124)\end{array}$ & $\begin{array}{l}0.029 * \\
(0.014)\end{array}$ & $\begin{array}{c}0.029 \\
(0.020)\end{array}$ & $\begin{array}{c}0.035 \\
(0.029)\end{array}$ \\
\hline Single female & $\begin{array}{c}0.042 \\
(0.038)\end{array}$ & $\begin{array}{c}0.010 \\
(0.078)\end{array}$ & $\begin{array}{c}0.021 \\
(0.141)\end{array}$ & $\begin{array}{c}0.015 \\
(0.013)\end{array}$ & $\begin{array}{l}-0.006 \\
(0.025)\end{array}$ & $\begin{array}{l}-0.028 \\
(0.033)\end{array}$ \\
\hline Age & $\begin{array}{c}0.009 * * * \\
(0.002)\end{array}$ & & & $\begin{array}{c}0.002^{* *} \\
(0.001)\end{array}$ & & \\
\hline Any children & $\begin{array}{c}0.023 \\
(0.052)\end{array}$ & $\begin{array}{c}0.056 \\
(0.054)\end{array}$ & & $\begin{array}{c}0.024 \\
(0.017)\end{array}$ & $\begin{array}{c}0.033 \\
(0.018)\end{array}$ & \\
\hline High school & $\begin{array}{c}0.498^{* * *} \\
(0.049)\end{array}$ & $\begin{array}{c}0.346^{* * *} \\
(0.052)\end{array}$ & & $\begin{array}{c}0.176^{* * *} \\
(0.017)\end{array}$ & $\begin{array}{c}0.120^{* * *} \\
(0.017)\end{array}$ & \\
\hline College & $\begin{array}{c}0.874^{* * *} \\
(0.058)\end{array}$ & $\begin{array}{c}0.575^{* * *} \\
(0.061)\end{array}$ & & $\begin{array}{c}0.286^{* * *} \\
(0.019)\end{array}$ & $\begin{array}{c}0.176^{* * *} \\
(0.020)\end{array}$ & \\
\hline Nonwhite & $\begin{array}{c}-0.395^{* * *} \\
(0.054)\end{array}$ & $\begin{array}{c}-0.246^{* * *} \\
(0.057)\end{array}$ & & $\begin{array}{c}-0.116^{* * *} \\
(0.019)\end{array}$ & $\begin{array}{c}-0.058^{* *} \\
(0.019)\end{array}$ & \\
\hline Hispanic & $\begin{array}{c}-0.681^{* * *} \\
(0.091)\end{array}$ & $\begin{array}{c}-0.614^{* * *} \\
(0.095)\end{array}$ & & $\begin{array}{c}-0.219 * * * \\
(0.031)\end{array}$ & $\begin{array}{c}-0.188^{* * *} \\
(0.032)\end{array}$ & \\
\hline Receiving Soc Sec & $\begin{array}{l}-0.036 \\
(0.035)\end{array}$ & $\begin{array}{c}0.060^{*} \\
(0.029)\end{array}$ & $\begin{array}{c}-0.049 \\
(0.075)\end{array}$ & $\begin{array}{c}-0.024^{*} \\
(0.011)\end{array}$ & $\begin{array}{l}-0.005 \\
(0.009)\end{array}$ & \\
\hline Year: 2000 & $\begin{array}{c}0.067^{*} \\
(0.028)\end{array}$ & $\begin{array}{c}0.069^{*} \\
(0.029)\end{array}$ & $\begin{array}{c}0.104 \\
(0.053)\end{array}$ & $\begin{array}{c}0.028^{* *} \\
(0.009)\end{array}$ & $\begin{array}{c}0.029^{* * *} * \\
(0.009)\end{array}$ & $\begin{array}{c}0.037 \\
(0.010)\end{array}$ \\
\hline Year: 2002 & $\begin{array}{c}-0.091^{* *} \\
(0.029)\end{array}$ & $\begin{array}{c}-0.074^{*} \\
(0.030)\end{array}$ & $\begin{array}{c}-0.115^{*} \\
(0.056)\end{array}$ & $\begin{array}{c}-0.025^{* *} \\
(0.009)\end{array}$ & $\begin{array}{c}-0.020^{*} \\
(0.009)\end{array}$ & $\begin{array}{l}-0.012 \\
(0.011)\end{array}$ \\
\hline Year: 2004 & $\begin{array}{c}-0.148^{* * *} \\
(0.030)\end{array}$ & $\begin{array}{c}-0.126^{* * *} \\
(0.030)\end{array}$ & $\begin{array}{c}-0.190^{* *} \\
(0.059)\end{array}$ & $\begin{array}{c}-0.044^{* * *} \\
(0.009)\end{array}$ & $\begin{array}{c}-0.036^{* * *} \\
(0.009)\end{array}$ & $\begin{array}{l}-0.028 \\
(0.012)\end{array}$ \\
\hline Year: 2006 & $\begin{array}{c}-0.387 * * * \\
(0.031)\end{array}$ & $\begin{array}{c}-0.368^{* * *} \\
(0.032)\end{array}$ & $\begin{array}{c}-0.594^{* * *} \\
(0.064)\end{array}$ & $\begin{array}{c}-0.107^{* * *} \\
(0.010)\end{array}$ & $\begin{array}{c}-0.100^{* * *} \\
(0.010)\end{array}$ & $\begin{array}{l}-0.088 \\
(0.013)\end{array}$ \\
\hline Constant & $\begin{array}{c}-7.944^{* * *} \\
(0.206)\end{array}$ & $\begin{array}{c}-8.944^{* * *} \\
(0.253)\end{array}$ & & $\begin{array}{c}-2.589^{* * *} \\
(0.065)\end{array}$ & $\begin{array}{c}-2.933^{* * *} \\
(0.080)\end{array}$ & \\
\hline Avg. marg. effect/coeff & 0.2546 & 0.2434 & & 0.2929 & 0.2865 & \\
\hline $\mathrm{N}$ & 44,718 & 44,718 & 15,174 & 43,838 & 43,838 & 41,067 \\
\hline
\end{tabular}

Notes: This table reports the coefficient estimates and standard errors (in parentheses) for random effects (RE), correlated random effects (CRE), and fixed effects (FE) specifications. The dependent variable in the ownership regressions is an indicator variable for whether the household owns a positive amount of stocks outside of retirement accounts. The dependent variable in the allocation regressions is the financial wealth share of stocks held outside of retirement accounts. Avg. marg. effect/coeff is the average ratio of the marginal effect to the coefficient estimate. Self-reported health $(1-5$, with $5=$ poor $)$ is the maximum reported value within a household. Prob. leave beq is the self-reported probability of leaving a bequest of at least $\$ 100,000$. Age is the maximum age within the household. Receiving Soc Sec is an indicator for whether the household receives at least $\$ 1,000$ of Social Security retirement benefits. 1998-2006 waves of the HRS. Values converted to 2006 dollars using the CPI-U. Statistical significance is indicated as follows: ${ }^{*} p<0.05,{ }^{* *} p<0.01,{ }^{* * *} p<0.001$. 